\title{
Er der stadig et A i NATO?
}

Af Tage Baumann

Det nye år var knapt to døgn gammel, da den amerikanske præsident Donald Trump samlede sit kabinet til krisemøde i Det Hvide Hus.

Det handlede om striden mellem præsidenten og kongressen om en ny finanslov, men det efterfølgende pressemøde brugte Trump til endnu en gang at nedgøre den indsats, USA's europæiske allierede har ydet i kampene i Afghanistan, Irak, Syrien og andre steder. "Hvad er det for en hjælp? 100 mand her og 100 mand der, det er jo ingenting", sagde han hånligt. "De udnytter os, det er urimeligt og det vil blive stoppet” sagde han også.

Sandt nok har den samlede militære indsats i Afghanistan siden 2001 haft en meget stor amerikanske overvægt, hvad der også hænger sammen med, at det var USA, der blev angrebet af alQaeda den 11. september 2001 i New York og Washington, at det derfor fra starten var amerikanernes krig, og at det også var sådan, USA så det: Amerikanerne afslog tilbuddet fra de andre
NATO-lande om at deltage solidarisk i Afghanistanoperation Enduring Freedom, da alliancen for første gang nogensinde aktiverede paragraf fem 'musketereden' i Washingtontraktaten som svar på terrorangrebene på World Trade Center og Pentagon. Hjertelig tak for tilbuddet, sagde USA til NATO, vi ringer, hvis vi får brug for jer. Amerikanerne satsede på en koalition med nøje udvalgte våbenbrødre, først og sidst briterne.

At de øvrige NATO-lande hen ad vejen kom til at yde en langt større indsats end ' 100 mand her og 100 mand der' fremgår af tabstallene. En opgørelse fra midten af 2018 viser, at mens USA havde 2.313 dræbte i Afghanistan 'og omegn', som der står i den amerikanske måde at opgøre tabstallet på, så er det samlede antal dræbte på koalitionssiden i Afghanistan i perioden oktober 2001 til 5. august 20183.458.

1145 faldne er med andre ord fra USA's allierede, 43 af dem danske. Og da en meget betydelig del af de amerikanske tab stammer fra den

Tage Baumann er sikkerhedspolitisk medarbejder på DR P1-programmet Orientering. 


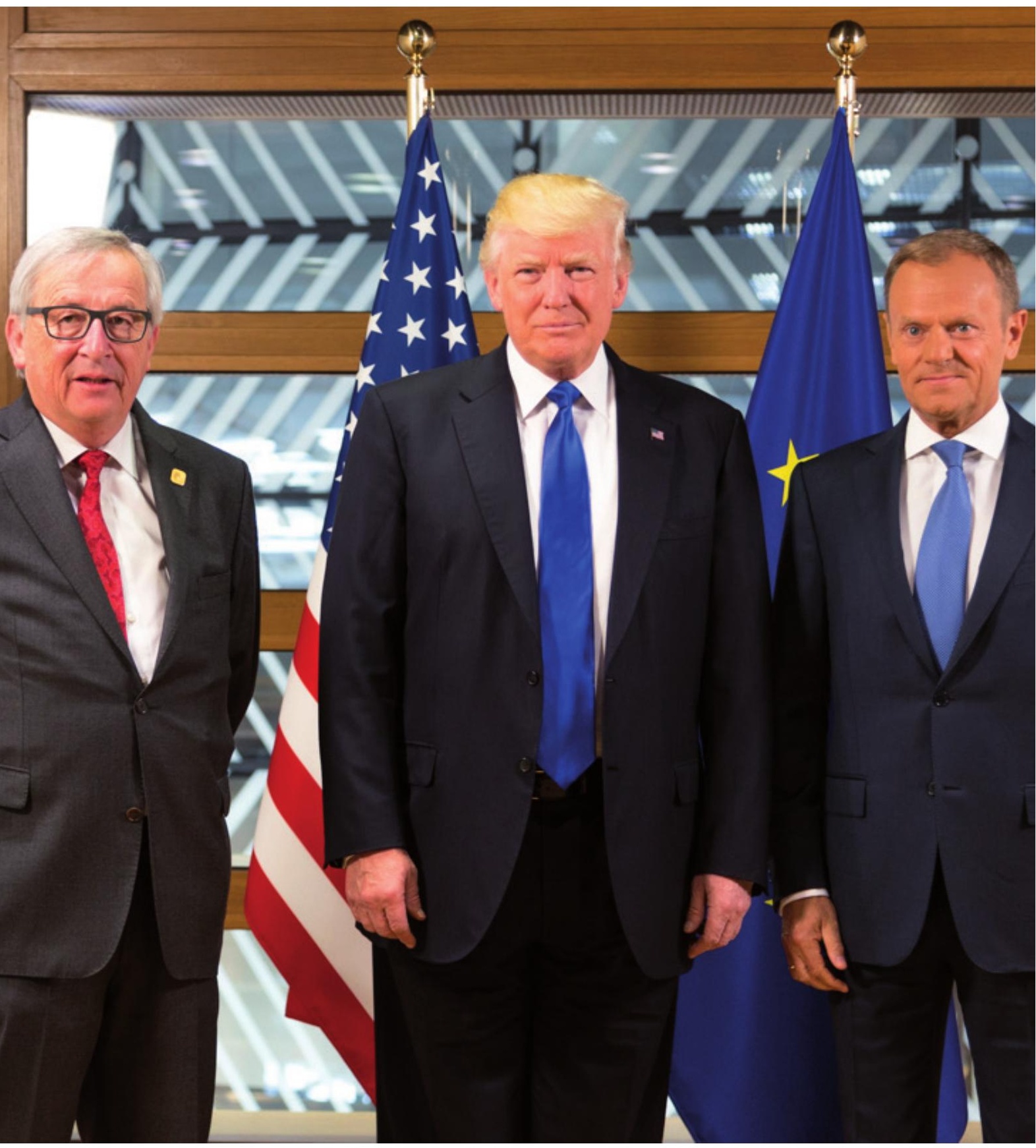

FOTO. : Det Hvide Hus, Washington DC

Donald Trump flankeret af Europa-Kommissionens formand, Jean-Claude Juncker, og formand for Det Europæiske Råd, Donald Tusk, den 25. maj 2017 i EU's hovedkvarter i Bruxelles 
En opgørelse fra midten af 2018 viser, at mens USA havde 2.313 dræbte i Afghanistan 'og omegn', som der står i den amerikanske måde at opgøre tabstallet på, så er det samlede antal dræbte på koalitionssiden i Afghanistan i perioden oktober 2001 til 5. august 20183.458. terroreksperter og efterretningskilder - også danske - mest. Som en terrorekspert højintensive krigsfase, altså Enduring Freedomoperationen, hvor de allierede som nævnt i begyndelsen ikke var velkomne (bortset fra de nøje udvalgte), så vil europæerne nok mene, at de i hele den efterfølgende ISAF-periode fra 2006 til 2015 har trukket et betydeligt læs i Afghanistan, i hvert fald nok til at den amerikanske præsidents hånlige foragt ikke opfattes som rimelig.

\section{USA ud af Syrien}

I politik taler handlinger højere end ord. Så mens europæerne måske er stødt over nedgøringen af deres bidrag i Afghanistan, Irak, Syrien, er der ingen tvivl om, at de er både vrede og bestyrtede over præsident Trumps beslutning om at trække de amerikanske styrker ud af Syrien, som blev sat i værk lige før årsskiftet, og Trumps planer om at trække halvdelen af den amerikanske 14.000 mand store Afghanistanstyrke ud af stabiliseringsog opbygningsarbejdet der.

Det sidste blev bekræftet af vicepræsident Mike Pence lige efter årsskiftet. Den tilbagetrækning kommer på et tidspunkt, hvor talibanstyrkerne igen har opbygget en betydelig kampkraft, og nok så vigtigt på et tidspunkt, hvor al-Qaeda er i færd med at genopfinde sig selv. Terrortruslen fra Islamisk Stat er ikke drevet over, men på længere sigt er det den genopbyggede trussel fra al-Qaeda, der bekymrer vestlige udtrykker det: hvis IS er vejret, så er al-Qaeda klimaet.

Set med europæiske øjne giver det meget lidt mening at forlade Syrien og Afghanistan og måske Irak netop nu. Og set fra Europa er det en besynderlig signalforvirring fra Washington på den ene side at forlange, at europæerne gør mere for at 'betale USA tilbage' for den sikkerhed, amerikanerne yder, og så på den anden side trække sig ud af internationale operationer efter først at have trukket europæerne med ind i dem.

For NATO er især Afghanistansignalet alvorligt, for netop Afghanistan i alliancen ses som det svendestykke, der skal vise, at NATO er i stand til at gennemføre en langvarig og omfattende indsats langt fra NATO's eget område uden at det går ud over alliancesolidaritet og sammenhold.

Det er et stykke af den nye postkoldkrig-NATO's selvforståelse, den amerikanske præsident her kradser i, og det gør ondt blandt allierede.

\section{Bølgegang}

Alliancen er i forvejen ude i politisk bølgegang, fordi den ikke på nogen måde var forberedt på en præsident Trump, hvis dagsorden især - og måske udelukkende - er indenrigspolitisk. En Trump, der under valgkampen kaldte alliancen en ting, der havde overlevet sig selv (obsolete), som synes at vægte handelspolitiske interes- 


\section{Det er et stykke af den nye postkold-krig-NATO's selvforståelse, den amerikanske præsident her kradser i, og det gør ondt blandt allierede.}

blandt meget andet blev kaldt uærlig og svag. Trumps økonomiske chefrådgiver ser højere end sikkerhedspolitiske, og som ikke holder sig tilbage med overfald på selv meget pålidelige allierede som Tyskland.

Det var i udkanten af NATO-topmødet i midten af 2018, han kaldte Tyskland 'Ruslands gidsel', fordi tyskerne køber gas i Rusland, og erklærede, at det vil han ikke finde sig i. "Hvorfor skal vi betale milliarder for at beskytte Tyskland og Frankrig mod Rusland, når de to lande samtidig smider milliarder efter netop Rusland", spurgte han ophidset for snurrende kameraer og åbne mikrofoner og torpederede på den måde generalsekretær Jens Stoltenbergs forsøg på at glatte ud og mægle og skabe god stemning for et topmøde, alle så som afgørende for det fremtidige forhold mellem USA og det europæiske NATO. Det blev det mest bizarre NATO-topmøde nogensinde.

Få uger tidligere chokerede den amerikanske præsident det internationale diplomati ved at bryde alle internationale spilleregler på det 44. topmøde i gruppen af de vigtigste industrilande, G7 topmødet i La Malbaie i Canada ved først at lade sin regering sige ja til et slutdokument og så - efter at det var blevet offentliggjort som topmøderesultatet af værten, den canadiske premierminister Justin Trudeau - trække USA's underskrift tilbage på vanlig Trump maner, dvs. per twitter fra sit fly på vej mod Singapore fra topmødet. Ledsaget af en strøm af ukvemsord mod netop Trudeau, der fulgte op med bemærkningen at 'der er en særlig plads i Helvede til Justin Trudeau'. Peter Navarro beklagede senere ordvalg, men ikke indhold i udtalelsen.

Lige så chokerende som Trumps fremgangsmåde omkring G7 topmødet var hans forsøg op til og under topmødet på at få de øvrige seks til at acceptere den russiske annektering af Krimhalvøen og invitere Rusland ind i G7 varmen igen. Det synspunkt var han alene om, og det sammen med den omstændighed, at Trump havde trukket, eller sagt at han ville trække, USA ud af en række internationale aftaler Paris-klima-aftalen og aftalen om Irans atomprogram var de mest omtalte - fik den franske præsident til at kalde G7 topmødet for et G6+1-topmøde: De seks mod det ene, helt isolerede USA.

\section{NATO-topmødet}

Og dermed var så stemningen lagt til NATO-topmødet. Diplomaterne fra alle alliancelandene, inklusive de amerikanske, var fast besluttet på at undgå en gentagelse af G7 balladen og sikre en topmødeerklæring, som alle kunne stå bag og stå ved.

Men starten var alt andet end lovende, for det var under et morgenmadsmøde med generalsekretær Jens Stoltenberg før topmødestarten, at præsident Trump kastede sig over de allierede. Frankrig og Tyskland stod for skud, men Tyskland helt specielt $i$ en lang argumentation, der toppede i bemærkningen om, at Tyskland var 
Den første topmødedag viste da også, at Trump ikke var faldet blandt ja-sigere og nikkedukker i det NATO, han i valgkampen havde erklæret for forældet, en organisation der har overlevet sig selv.

Ruslands gidsel (a captive of Russia) på grund af den tyske gasimport fra Rusland og den planlagte gasledning NordStream 2 gennem Østersøen.

Det fik kansler Angela Merkel til at svare, at hun, der var vokset op i DDR under russisk dominans, var glad for, at et frit og genforenet Tyskland nu kunne træffe egne suveræne beslutninger også om sin energipolitik. For Angela Merkel var det en usædvanlig bramfri tilrettevisning af den amerikanske præsident. Og den første topmødedag viste da også, at Trump ikke var faldet blandt ja-sigere og nikkedukker i det NATO, han i valgkampen havde erklæret for forældet, en organisation der har overlevet sig selv.

Han fik kamp til stregen i diskussionen om de europæiske forsvarsudgifter, som han forlangte hævet til to procent af landenes bruttonationalprodukt her og nu, på stedet. Og, som han sagde, 'det er ikke nok, der bør være fire pct. De øvrige NATO-lande fastholdt beslutningerne fra topmøderne i Wales og Warszawa og bekræftede, at de arbejder hen mod målet på to pct. i 2024.

Trump fik den indrømmelse, at landene lovede hinanden at fremskynde processen mest muligt. Og topmødet vedtog allerede på førstedagen en række nye initiativer, som især har at gøre med stabiliseringen af sikkerheden $\mathrm{i}$
Østersøområdet. Det var lidt ømtåleligt, netop fordi Trump på G7 mødet havde talt for at acceptere den russiske annektering af Krim, og fordi den amerikanske præsident uden konsultationer med sine allierede og tilsyneladende uden synderlige forberedelser havde sagt ja til at møde den russiske præsident Vladimir Putin i Helsinki umiddelbart efter topmødet i Alliancen. På NATO-topmødet ville Trump ikke lægge sig fast på, hvad han ville og ikke ville indgå af aftaler med Rusland i Helsinki.

Det lykkedes diplomatiet bag topmødet at få tømret en sluterklæring sammen, som blev accepteret af alle parter allerede om aftenen på den første topmødedag. Arbejdsmiddagen forløb ifølge det, der sivede ud fra den, i nogenlunde harmoni. Især, sagde rygterne, fordi det lykkedes de andre at overtale Donald Trump til at fortælle om det helt uventede topmøde, han havde fået i stand med Nordkoreas leder Kim Jong-un om det nordkoreanske atomvåbenprogram, et topmøde der blev gennemført mellem G7 mødet og NATO-mødet.

Så NATO-mødets andendag startede med nyheden om, at en sluterklæring var på plads, og at alle stod bag den. I pressepavillonen ved det nye NATO-hovedkvarter i Bruxelles gik spøgefulde væddemål i gang belært af G7 mødet: hvor hurtigt ville Trump trække den underskrift tilbage? Lige så hurtigt som G7 erklæringen, eller måske et par timer senere?

I første omgang åndede alt fred og fordragelighed. Præsidenterne fra Georgien og Ukraine var inviteret til da- 
gens første møde for at alliancen kunne vise solidaritet med de to lande, der var udsat for et helt særligt stort pres fra russisk side. Men det møde blev brat afbrudt, fordi den amerikanske præsident pludselig åbnede hele diskussionen om de europæiske forsvarsudgifter igen og satte spørgsmålstegn ved den sluterklæring, der var enighed om bare få timer tidligere.

De to gæstende præsidenter blev bedt om at forlade lokalet, og derefter blev der talt med store bogstaver i NATO-kredsen bag lukkede døre. Blandt os journalister steg spændingen og en fornemmelse af at opleve noget fuldkommen utroligt $\mathrm{i}$ NATO-sammenhæng. Og den fornemmelse blev ikke mindre, da det hele så endte med et Trump-pressemøde, hvor præsidenten erklærede topmødet for en stor succes og sig selv som NATO’s største fan. Ikke et komma var blevet ændret i sluterklæringen fra aftenen før.

De øvrige NATO-lande havde holdt stand, i hvert fald på papiret. Hvilke løfter eller tilsagn Trump fik under hånden undervejs $\mathrm{i}$ processen den morgen ved kun de, der deltog i mødet. Han tog uimodsagt æren for de løft i de europæiske forsvarsudgifter, der var sket fra Wales-topmødet og frem til dato, altså i perioder hvor han endnu ikke var præsident.

\section{Mellemdistancevåben}

Trump tog videre til Putin-mødet i Helsinki og chokerede på det møde muligvis sine egne landsmænd endnu mere end omverdenen ved tilsyneladende at købe stort set hele den russi- ske dagsorden og på den måde starte en ny diskussion om, hvor stor indflydelse den russiske præsident har på Trumps politik, og af hvilken art den indflydelse er.

Spørgsmålet er kompliceret, fordi

På den ene side synes præsidenten $\mathrm{i}$ Washington parat til at købe mange af Putins argumenter og forklaringer, på den anden side har han trukket USA ud af væsentlige aftaler med Rusland.

signalerne fra Trump er modstridende: på den ene side synes præsidenten $\mathrm{i}$ Washington parat til at købe mange af Putins argumenter og forklaringer, på den anden side har han trukket USA ud af væsentlige aftaler med Rusland. Som ABM-traktaten om ballistiske missiler. Og true med at trække USA ud af traktaten om begrænsning af mellemdistanceatomvåben, INF-traktaten (USA meddelte i begyndelsen af februar 2019, at det ikke længere føler sig bundet af INF-traktaten (red.)). Det sidste ser europæerne i NATO kun meget nødigt ske, for de nukleare mellemdistancevåben er først og fremmest våben udviklet til brug i Europa.

INF-problemet bliver et hovedproblem for NATO, hvis det ikke lykkes at få en ny forståelse i stand mellem USA og Rusland på mellemdistanceatomvåben-området. Alliancen må forberede sig på en diskussion om mellemdistanceatomvåben, lød nytårsbudskabet fra NATO's generalsekretær Jens Stoltenberg i interviews, han gav i forbindelse med årsskiftet, for eksempel til det tyske nyhedsbureau DPA. 
Noget forenklet er konflikten den, at Rusland siger, at USA længe har forberedt et brud på INF-traktaten, der forbyder begge parter at have den slags våben $\mathrm{i}$ landbaserede udgaver, ved blandt andet at videreudvikle landbaserede udgaver af de affyringsanlæg til Tomahawk-krydsermissiler, som amerikanerne har på deres skibe. Amerikanerne fastholder, at det er nonsens, men det er ikke desto mindre de russiske påstande. USA har omvendt længe sagt, at Rusland muligvis bryder traktaten med de russiske Iskander-missiler, der fx er opstillet i Kaliningrad-området, og som amerikanerne siger kan medføre atomvåben. Russerne siger, at det er nonsens. Konflikten er senest optrappet, fordi Rusland har udviklet et nyt våben, SSC-8, som ifølge USA og NATO er et landbaseret, atombærende mellemdistance-missil - en klar overtrædelse af INF-traktaten.

\section{Europæisk debat?}

Præsident Trump besluttede ved årsskiftet at trække USA ud af INF-aftalen, hvad der vil betyde, at aftalen ikke længere eksisterer, for det er en aftale alene mellem Washington og Moskva. Trump dropper INF-aftalen, med mindre Rusland inden for en frist på 60 dage giver afkald på de nye våben, lød det ved årsskiftet.

Når Jens Stoltenberg for længst er $i$ gang med at forberede alliancen på denne diskussion skyldes det, at et logisk militært svar på en russisk oprustning med landbaserede mellemdi- stance-missiler vil være en amerikansk oprustning med landbaserede mellemdistance-missiler med atomsprænghoveder. Og den eneste logiske placering af den slags missiler vil være i Europa. En ny mellemdistancedebat vil udfordre NATO på tre måder.

For det første fordi en fremtid uden en aftale alt andet lige vil betyde et nyt våbenkapløb på atomvåben på europæiske område, og det vil en væsentlig del af de europæiske NATO-lande være meget lidt tilfreds med. Ikke mindst fordi sådan et kapløb mellem Rusland og USA på europæisk område dramatisk vil forringe europæernes muligheder for at finde en eller anden sikkerhedspolitisk forståelse med Rusland i NATO's grænseområder mod øst og mod syd, og måske mod nord i det arktiske område.

For det andet fordi vesteuropæerne ikke har glemt, hvordan det første mellemdistancekapløb i slutningen af 1970'erne og begyndelsen af 1980'erne var ved at rive selv den mest fundamentale politiske konsensus i stykker: hverken tyskerne eller briterne har glemt den folkelige modstand mod udstationeringen af de 572 krydsermissiler og Pershing II raketter, der dengang var tale om. Den britiske Greenham Common base og de voldsomme protestaktioner blev symbolet på det opgør. Og den mistro mellem øst og vest, som 
det opgør såede, var en del af forklaringen på det lavpunkt i den kolde krig, der blev nået $\mathrm{i}$ begyndelsen af firserne med Ronald Reagan i Det Hvide Hus, Margaret Thatcher i Downing Street 10 og en paranoisk, alderstegen ledelse i Kreml.

Der er forskere, som i dag hævder, at verden i 1983 var tættere på en ny verdenskrig end på noget andet tidspunkt under den kolde krig, og den europæiske del af NATO, der også var med i alliancen den gang, har ikke glemt, hvor svag og hjælpeløs Europa var i det opgør.

\section{NATO eller udenfor}

Den tredje måde, en ny INF-debat udfordrer NATO på, er ved at udfordre sammenhængen i alliancen forstået på den måde, at en ny amerikansk oprustning med mellemdistanceatomvåben i Europa ikke nødvendigvis vil ske inden for NATO-rammen.

\section{Det er ikke utænkeligt, at baltiske eller østeuro- pæiske NATO-lande er villige til at lade USA udstationere landbaserede mellemdistance atomvåben på deres område, mens det omvendt allerede nu er klart, at nogle af de betydelige vesteuropæiske NATO-lande vil sige fra.}

Det er ikke utænkeligt, at baltiske eller østeuropæiske NATO-lande er villige til at lade USA udstationere landbaserede mellemdistance atomvåben på deres område, mens det omvendt allerede nu er klart, at nogle af de betydelige vesteuropæiske NATO-lande vil sige fra. Det gjorde den tyske udenrigsminister Heiko Maas helt klart i et interview med det tyske nyhedsbureau DPA den 26. december: "Europa må under ingen omstændigheder blive skueplads for en oprustningsdebat. En udstationering af nye mellemdistanceraketter vil møde bred modstand i Tyskland."

En særlig udfordring for NATO bliver i givet fald at holde debatten strengt til en diskussion om nye mellemdistancevåben i Europa som modsvar og afskrækkelse over for en russisk oprustning. Det store problem med INF-diskussionen for 40 år siden var, at motiverne var mudrede på europæisk side. Et væsentligt element i debatten var ledende europæiske politikeres ønske om at bruge et ja til de nye våben som middel til at binde amerikanerne til en fortsat militær tilstedeværel-
Hvis NATO ikke kan nå en eller anden fælles forståelse i INF-spørgsmålet i tilfælde af, at aftalen bliver skrottet, så har USA muligheden for at lave aftaler med nogle europæiske NATO-lande uden for NATO-rammen. Modellen er i grove træk kendt fra det amerikanske raketskjoldprogram, der også arbejder med bilaterale aftaler med NATO-lande som Polen, men uden for NATO-rammen. se i Europa. Frygten var, at præsident Jimmy Carter kunne finde på at trække amerikanske styrker ud af Vesteuropa $i$ et omfang, der ville undergrave NATO's afskrækkelsesmulighed.

Resultatet var, at offentligheden blev præsenteret for én argumentation, mens argumentationen bag kulisserne delvis løb ad andre spor, hvad der bidrog til at gøre det folkelige opgør om raketterne så forbitret. 


\section{Patrioter mod globalister}

Så konflikter både hen over Atlanten og europæerne imellem er forprogrammeret, hvis det kommer til et nyt INF-kapløb mellem USA og Rusland.

lidt senere sagde hun: "Vi europæere må virkelig tage vores egen skæbne i vores egen hånd”. Det var i maj 2017, og hun har i interview efter interview siden da gentaget det budskab: at Europa skal kunne selv, og at Europa også skal ville selv.

Det er blevet stadig tydeligere, at der er en europæisk dagsorden, der ikke længere automatisk går ud fra en grundlæggende forståelse med USA. I EU-rammen viser det

Europæerne kan ikke være i tvivl om, at bilaterale aftaler mellem USA og enkelte NATO-lande vil være mere i tråd med tankegangen hos Donald Trump og kredsen omkring ham end kollektive aftaler i NATO. Trump og hans politiske venner taler ikke om isolationisme, sådan som deres kritikere i og uden for USA gør.

Trumpianerne taler gerne om patriotisme som modsætning til globalisme. De vil ikke trække sig ud af verdenssamfundet, men lave aftaler med andre lande en-til-en i en ramme der sikrer, at USA er den stærke part i forhandlingerne. Det gælder i handelspolitiske forhandlinger, som det gælder i sikkerhedspolitiske, og europæerne både i EU og i NATO har allerede draget ganske vidtgående konklusioner, der yderligere kommer til at udfordre NATO i de kommende år.

Allerede få måneder efter at Donald Trump var blevet indsat som amerikansk præsident, sagde den tyske kansler - i et øltelt i Bayern - en sætning, der dengang blev tolket i mange retninger. Hun sagde: "De tider, hvor vi kunne stole helt på andre, er delvis forbi“. Og sig på det sikkerhedspolitiske område i gennembruddet for en europæisk forsvarsunion, om end PESCO-samarbejdet i første omgang fokuserer på rustningsindustriel forskning, udvikling og produktion. Perspektivet er et andet og større i både fransk og tysk optik. Halvandet år efter øltelttalen gjorde den tyske kansler det endnu tydeligere, hvad hun mente. I Europa-Parlamentet i Strasbourg sagde hun den 13. november 2018: "Vi bør arbejde på en vision om en dag også at skabe en ægte europæisk hær". Og gentog at de tider, hvor Europa kunne stole på andre, ganske enkelt er forbi.

\section{Europæisk konkurrence}

For NATO rejser det spørgsmålet - alle tyske og franske bedyrelser om det modsatte til trods - om der hér viser sig omridset af en europæisk konkurrent til NATO. Under alle omstændigheder må NATO ret hurtigt forsøge at afgøre med sig selv, hvordan den her udfordring skal mestres i fremtiden.

Endnu er det ikke klart, i hvilken retning den europæiske udvikling kommer til at gå: et overstatsligt EU-militær, et 
Sikkert er kun, at fænomenet Donald Trump, som europæerne for længst er på det rene med, repræsenterer en reel og betydelig del af det amerikanske folk, har fremskyndet de europæiske ambitioner, og at briternes beslutning om at forlade EU har fjernet den tungeste bremseklods for en forsvarspolitisk udvikling i EU.

mellemstatsligt 'europæernes forsvar' eller en konstruktion ingen endnu har udtænkt. Sikkert er kun, at fænomenet Donald Trump, som europæerne for længst er på det rene med, repræsenterer en reel og betydelig del af det amerikanske folk, har fremskyndet de europæiske ambitioner, og at briternes beslutning om at forlade EU har fjernet den tungeste bremseklods for en forsvarspolitisk udvikling i EU.

Frankrigs præsident Emmanuel Macron har kastet endnu et kort ind i det sikkerhedspolitiske spil med forslaget om at opbygge europæiske militære kapaciteter 'uden for EU og uden for NATO. En styrke, der skal gøre Europa i stand til at operere militært i sine nærområder mod syd, Afrika, og mod sydøst, Mellemøsten. Det er en konstruktion, der tillader briterne at være med i et europæisk militært samarbejde uden for NATO, også efter at briterne har forladt EU. Det store og uafklarede spørgsmål er, om det her er et resultat af, at de transatlantiske bånd er alvorligt svækkede, eller om de her initiativer netop er med til at svække de transatlantiske bånd?

\section{Modsatte signaler}

Der er modsatte signaler. Et større fælles NATO-engagement i Østersøområdet for eksempel og genetab- leringen af en NATO-kommando for sikring og eventuelt forsvar af forsyningsvejen mellem USA og Europa over Nordatlanten. Det er truslen fra Rusland, som den opfattes efter Ruslands annektering af Krimhalvøen, og Ruslands stigende politiske, militære og økonomiske pres mod dele af NATO-området, først og fremmest de baltiske lande, der har fremmet de beslutninger, og som også har aktualiseret debatten i NATO om forsvarsudgifterne. Den debat blev startet, ikke af Donald Trump men af præsident Obama umiddelbart efter Krim-annekteringen i 2014, og den fortsætter den dag i dag.

Konflikten med Rusland har også været katalysator for andre større NATO-initiativer, for eksempel på områder som cybersikkerhed, spørgsmål om NATO-landenes modstandsdygtighed over for angreb på deres kritiske infrastruktur og diskussionen om forsvar mod påvirkningsoperationer i forbindelse med for eksempel valg og andre politiske processer i NATO-landene.

Alt det er vigtigt, meget vigtigt endda. Men det store spørgsmål, NATO skal finde svar på, er spørgsmålet om Angela Merkel har ret: er de tider forbi, 
hvor europæerne kunne stole på andre, kunne stole på USA? Er der stadig et atlantisk A i NATO?

\section{Oversætterne}

Det er tidligere set, at amerikanerne og europæerne talte to forskellige sprog, og der har altid været villige oversættere, som sørgede for at bringe de transatlantiske partnere sammen, når de talte forbi hinanden. Ofte er den slags tolkning sket i udkanten af den årlige sikkerhedskonference i München. Det var for eksempel i München i 2017, at den amerikanske forsvarsminister James Mattis forklarede europæerne, at Donald Trump ikke havde afskrevet NATO som noget, der har overlevet sig selv. Og europæerne trøstede sig med, at de i det mindste havde forstående ører i den amerikanske kongres, helt specielt hos senator John McCain.

Men det var 2017 og 2018. Nu har vi 2019. Jim Mattis er ikke længere amerikansk forsvarsminister, og John McCain er død. Mange af de andre 'oversættere' i Washington er heller ikke længere aktive. Ikke Joe Liebermann, ikke John Kerry, ikke Joe Biden, for bare at nævne tre. Og senator Lindsey Graham har et så ambivalent forhold til præsident Trump, at han muligvis ikke kan spille nogen oversætterrolle længere.

I Washington siger man lidt ondskabsfuldt, at med Jim Mattis har den sidste voksne forladt kredsen omkring præsidenten. Der er ikke længere nogen, der kan forklare Donald Trump, hvorfor NATO er vigtig, og der er ikke længere nogen, der kan forklare europæerne, hvorfor Donald Trumps pointer måske ikke alle er lige urigtige.

Tilbage er så at lytte til, hvad manden selv siger. Og med den twitterkultur, han helt er forsvundet ind i, kan han gøre det kort og klart. Efter budgetkrisemødet med kabinettet den 2. januar svarede Donald Trump på et spørgsmål fra en journalist: "Jeg er ligeglad med europæerne. Jeg er valgt af amerikanerne".

Det er også den virkelighed, NATO skal indstille sig på. 